\title{
THE EFFORTS TO OVERCOME STUDENTS' MISCONCEPTIONS ON SCIENCE LEARNING SUB-CONCEPT BIOTECHNOLOGY AT MTSPN 4 MEDAN
}

\section{Nasution S, Febrina J, and, Sitanggang W}

Department of Science Education Universitas Negeri Medan saidatunnisanst@mhs.unimed.ac.id

Accepted: November $19^{\text {th }}, 2021$. Published: December $31^{\text {th }}, 2021$

\begin{abstract}
The purpose of this study was to determine the efforts to overcome students' misconceptions in learning science, especially in biotechnology material. The method used in this research is descriptive method with qualitative and quantitative approaches. The research population was all students of class IX MTsPN 4 Medan in the academic year 2021/2022, totaling 20 people. Determination of data sources/subjects of this research is based on cluster sampling technique because the number of informants is relatively small and random, less than 30 people. Previous research literature is also used as additional material. Data collection techniques using test and interview techniques. Data collection in this study used a test in the form of multiple choice accompanied by CRI (Certainty of Response Index). The data obtained from the results of the study were then analyzed using descriptive statistical techniques, to distinguish students who understand concepts, misconceptions and do not understand concepts. The results obtained that there were misconceptions about science lessons, especially biotechnology material in class IX students of MTsPN 4 Medan in the 2021 academic year with a level of $15.46 \%$ in the subconcepts of basic principles of biotechnology, $9.81 \%$ in conventional biotechnology, $17.85 \%$ in modern biotechnology. , and $18.44 \%$ in the sub-material of the application of biotechnology. Based on the results of the study, the causes of student misconceptions can occur because of the individual himself, the debriefing that students receive and the handbook. Efforts that can be made to reduce the occurrence of misconceptions are the provision of material according to the concept, detailed explanations, and discussions.
\end{abstract}

Keywords: Science Misconceptions, Biotechnology, Science Learning 


\section{Introduction}

Science is rational and objective knowledge about the universe and all its contents (Darmojo; 2006). Before starting science learning, sometimes in students' minds, an initial concept is embedded which they get from the experience of everyday life. In learning science students have a lot of experience and knowledge related to nature. All students already have a lot of experience about motion, force, electricity, magnetism, energy, about living things, inanimate objects and many other natural events that are known by students before carrying out the learning process regardless of whether their knowledge is correct according to the "concept" or not. With this experience, intuition and "student theory" have been formed regarding natural events in the daily environment of humans, but not necessarily the intuition and theory that have been formed are correct. This experience forms students' intuition about science concepts which are not necessarily true with scientific concepts according to experts, the incompatibility of students' intuition with scientific concepts based on these experts is called misconceptions.

Misconception is a conception that is attached to the minds of students which actually deviates from the concepts put forward by experts, which will make students mistaken in understanding natural phenomena. Misconceptions are students who think that their conceptions are correct and ignore scientific concepts, so that in learning students' thinking will be contrary to scientists. Misconceptions (misconceptions) arise from everyday experience and are very difficult to correct. If the teacher teaches without paying attention to the student's misconceptions (misconceptions) that already exist in his head before experiencing the learning process at school, the teacher will not succeed in instilling the correct science concepts. Therefore, it is necessary to anticipate consistently from an early age to make learning improvements starting from the analysis of conceptual errors to finding alternative solutions regarding how misconceptions in science learning might be overcome. The purpose of this study was to identify misconceptions about science learning in the biotechnology concept of class IX students at MTsPN 4 Medan and efforts to overcome them.

\section{Research Method}

The method used in this research is descriptive method with qualitative and quantitative approaches.

The data sources/research subjects in this study were all students of class IX MTsPN 4 Medan in 2021/2022, totaling 20 people. Determination of data sources/subjects of this research is based on cluster sampling technique because the number of informants is relatively small and random, less than 30 people. Previous research literature is also used as additional material.

Data were collected using test and interview techniques. The test technique uses a data collection tool/instrument in the form of multiple-choice questions. Students must write down the confidence index to the answer (CRI), which is the number 0-5. This CRI scale is placed together with multiple choice questions from each item and is filled in by each class IX student based on the student's level of confidence in answering the questions.

The research uses quantitative methods. Quantitative method or approach is research that produces findings that can be achieved (obtained) by using statistical procedures or other means of quantification (measurement). The population in this study were several grade IX students at MTsPN 4 Medan, in the 2021/2022 academic year. Sampling in this study using cluster sampling technique (Sugiyono, 2008). Determination of clusters by means of random or random. Random is not done directly on all students, but on the class / school as a group or cluster. Data collection in this study used a test in the form of multiple choice accompanied by CRI (Certainty of Response Index). The data obtained from the results of the study were then analyzed using descriptive statistical techniques, to distinguish students who understand concepts, misconceptions and do not understand concepts, they can use the 
CRI (Certainty of Response Index) criteria in Table 1 below.

Table 1. Provisions of Test Question Answers combined with CRI Criteria

\begin{tabular}{c|l|l}
\hline $\begin{array}{c}\text { Answer } \\
\text { Criteria }\end{array}$ & \multicolumn{1}{|c|}{$\begin{array}{c}\text { Low CRI } \\
(<\mathbf{2 . 5})\end{array}$} & \multicolumn{1}{|c}{$\begin{array}{c}\text { High CRI } \\
(>\mathbf{2 . 5})\end{array}$} \\
\hline $\begin{array}{l}\text { Correct } \\
\text { answer }\end{array}$ & $\begin{array}{l}\text { Correct } \\
\text { answer but } \\
\text { low CRI } \\
\text { means don't } \\
\text { know the } \\
\text { concept }\end{array}$ & $\begin{array}{l}\text { Correct } \\
\text { answer and } \\
\text { high CRI } \\
\text { means know } \\
\text { the concept }\end{array}$ \\
\hline $\begin{array}{l}\text { Wrong } \\
\text { answer }\end{array}$ & $\begin{array}{l}\text { Wrong answer } \\
\text { and low CRI } \\
\text { means don't } \\
\text { know the } \\
\text { concept }\end{array}$ & $\begin{array}{l}\text { Wrong answer } \\
\text { and high CRI } \\
\text { means there is } \\
\text { a } \\
\text { misconception }\end{array}$ \\
\hline
\end{tabular}

\section{Result and Discussion}

Result

The test questions are divided into 4 sub-concepts with 20 items being tested on 28 grade IX students. The results of student answers IX MTS. Negeri 2 Medan from a multiple choice test accompanied by a level of confidence (Certainty of Response Index) in biotechnology material which is divided into 3 categories, namely Understanding (P), Misconceptions (M) and Don't Understand (TP) concepts. The following is a table of percentages of the answers of class IX students at MTSPN 4 Medan.

Table 2. Percentage of Students Based on Answers and Level of Trust (Certainty of Response Index) Category Understand (P), Misconceptions (M) and Don't Understand (TP) on Biotechnology material

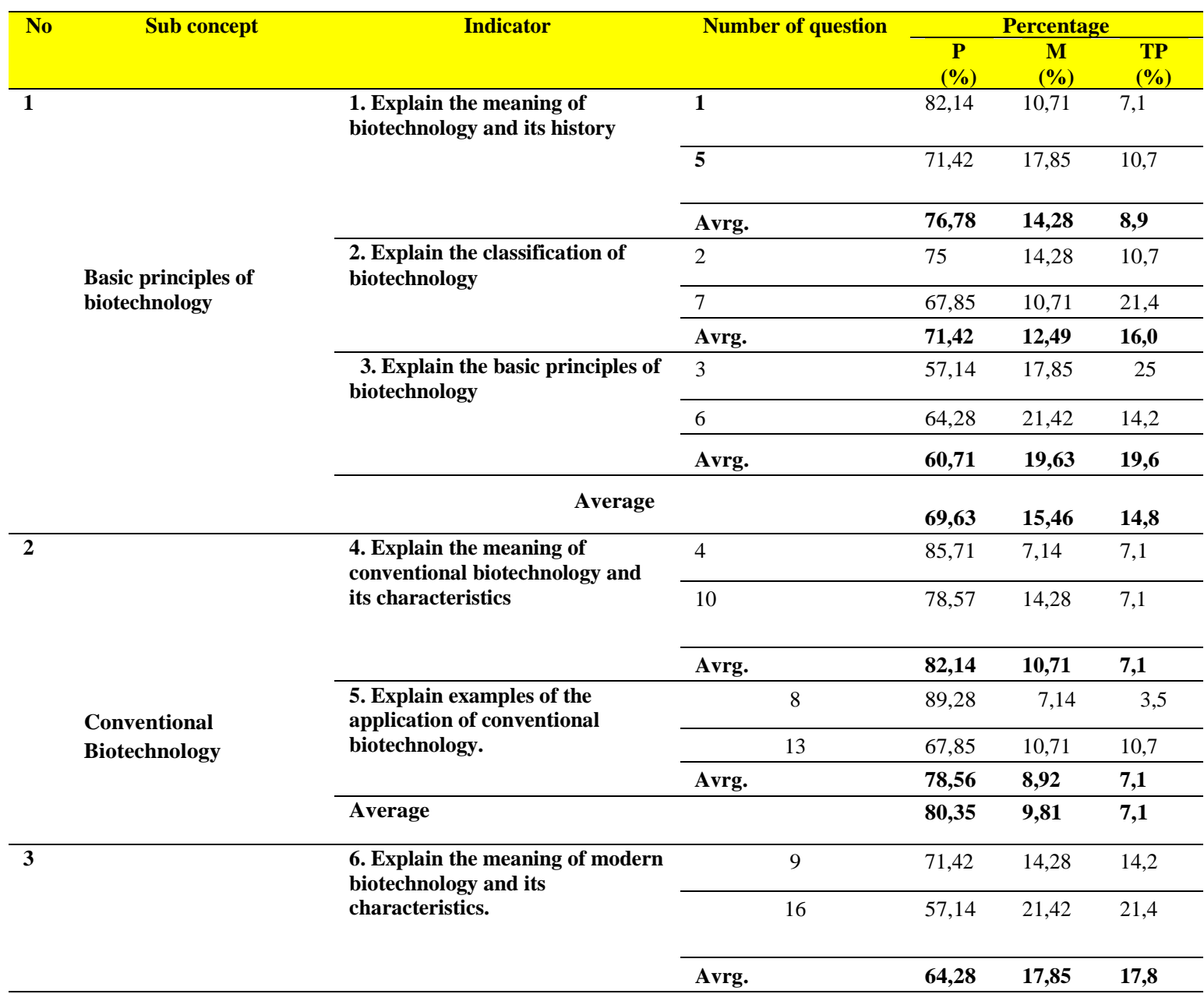




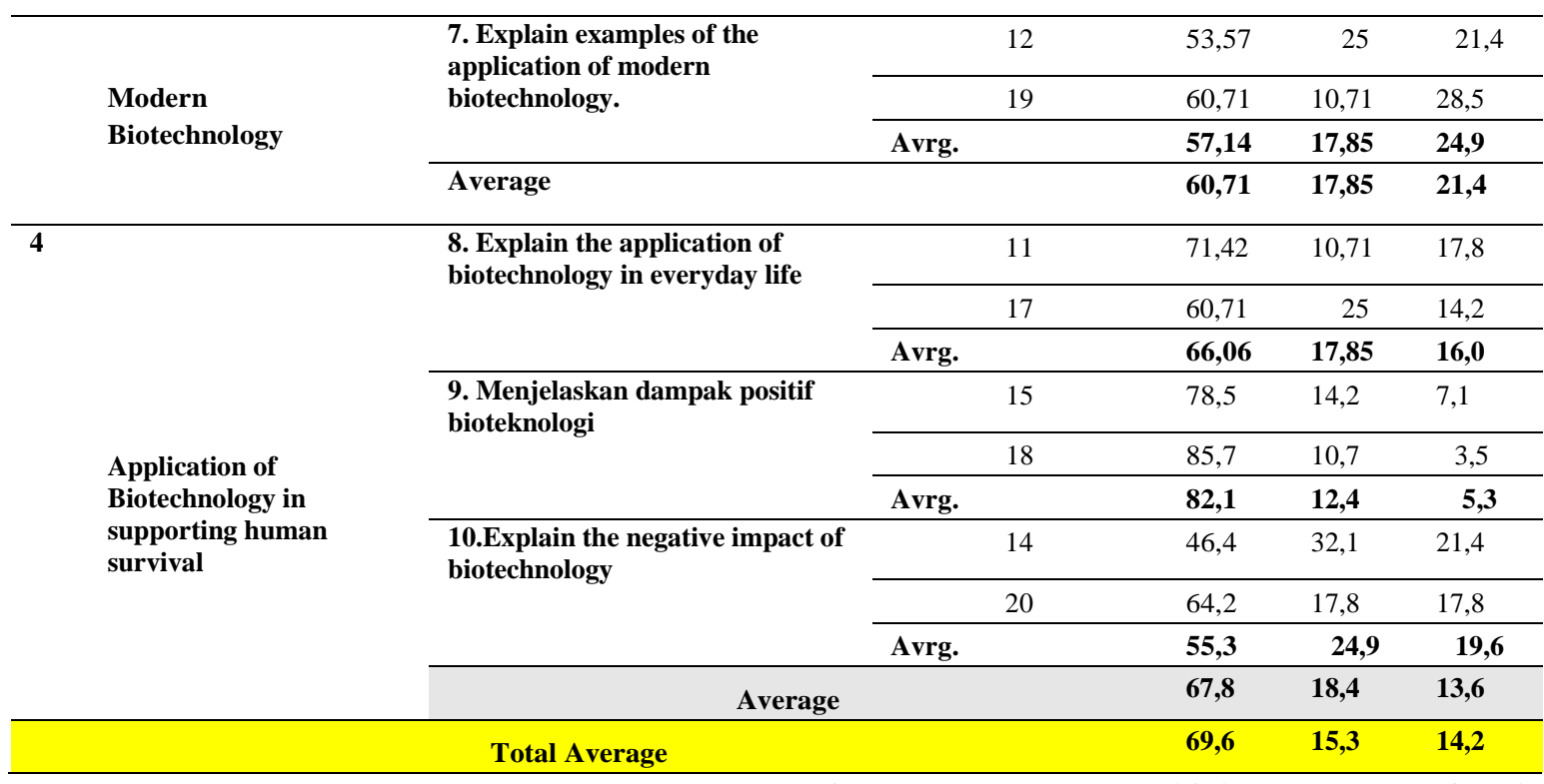

Based on Table 2, it can be seen that the class IX students at MTsPN 4 Medan. Misconceptions are found in all sub-concepts of Biotechnology material, namely the basic principles of biotechnology at $15.46 \%$, Conventional Biotechnology at $9.81 \%$, Modern Biotechnology at $22.31 \%$ and Application of Biotechnology to support the survival of human life by $18.44 \%$.

To find out the items that were misconceived and the items that were not understood (didn't understand) as a group, it could be seen from the CRI value for

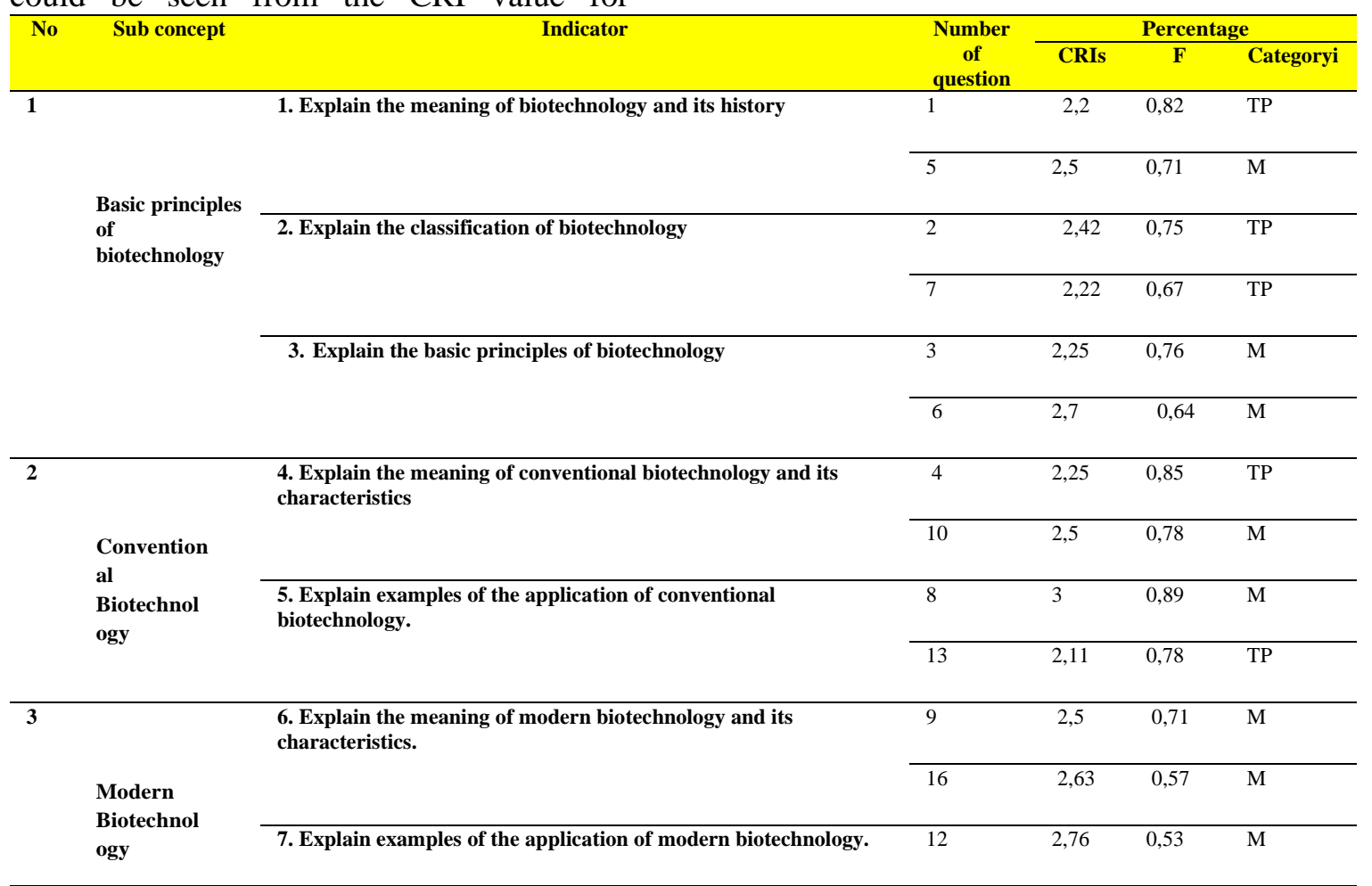

incorrect answers which were associated with the fraction value. The CRI score can be obtained by dividing the total CRI score for incorrect answers by the number of students who answered incorrectly per item. Meanwhile, to get the value of the fraction that is by dividing the total number of students who answered correctly by the total of all students. Table 3 is a tabulation of data on CRIs and $\mathrm{F}$ values.

Table 3. CRI Values for Wrong Answers (CRIs) and Fractions (F) 


\begin{tabular}{|c|c|c|c|c|c|c|}
\hline & & & 19 & 2,27 & 0,60 & $\mathrm{TP}$ \\
\hline \multirow[t]{5}{*}{4} & \multirow{5}{*}{$\begin{array}{l}\text { The application } \\
\text { of } \\
\text { Biotechnology } \\
\text { supports the } \\
\text { survival of life. }\end{array}$} & 8. Explain the application of biotechnology in everyday life & 11 & 2,5 & 0,71 & M \\
\hline & & \multirow[t]{2}{*}{ 9. Explain the positive impact of biotechnology } & 15 & 2,5 & 0,78 & M \\
\hline & & & 18 & 2,25 & 0,85 & TP \\
\hline & & \multirow[t]{2}{*}{ 10. Explain the negative impact of biotechnology } & 14 & 2,66 & 0,46 & $\mathrm{M}$ \\
\hline & & & 20 & 2,7 & 0,64 & M \\
\hline
\end{tabular}

In Table 3, the existence of fraction values is needed to analyze the items as a whole, between the number of groups of students who answered correctly and incorrectly. If the CRIs value is above the threshold of 2.5 and the fraction value is low $(<0.5)$, it can be decided that the question belongs to the category that is being misconceived. If the CRI scores are above the threshold of 2.5 and even exceed three with a high fraction value (>0.5), then the question is still categorized as a question that is misconceived by students. However, if the CRIs score is below the threshold of 2.5 and the fraction value is low $(<0.5)$ or high $(>$ $0.5)$ then the question is included in the category of questions that students do not understand.

Based on the explanation above, from Table 3 it can be identified that students tend to have misconceptions on each sub-concept in Biotechnology material. In the sub-concepts of the basic principles of biotechnology in questions number 3,5 , and 6 are items that are misconceived, while items that are not understood are questions number 1,2 and 7. 10, while the items that are not understood are questions number 4 and 13. The sub-concept of modern biotechnology, the items that are misconceived are questions number 9, 12, and 16, while the questions that are not understood are question number 19. Meanwhile, in the sub-concept of applying biotechnology in support the continuity of human life questions number $11,14,15,17$, and 20 are items that are misconceived and questions that are not understood, namely question number 18 .

\section{Discussion}

The next process, after knowing the students' understanding through multiple choice tests accompanied by CRI, can identify students who have misconceptions. Furthermore, the researchers conducted an analysis of the answers of students who experienced misconceptions, on the questions with the highest percentage in each sub-concept of biotechnology material.

\section{a. Basic principles of biotechnology}

To find out students' understanding of the basic principles of biotechnology used questions number $1,2,3,5,6$, and 7 . The highest percentage of this sub-concept is on questions number 3 and 5 , which is $17.85 \%$. In question number 5 students are asked to answer the technology that utilizes microorganisms. The percentage of students who have misconceptions is $17.85 \%$ with a fraction value of 0.71 or 16 people who can answer correctly and are supported by a high CRIs score (> 2.5) which is 2.5. In this question, students who experience misconceptions choose the answer of tissue culture which should be fermentation. Based on these answers, students only understand the concept partially, without going into it again, so students are not right in choosing the answers they hear more often. Because the number has a high fraction value and the CRIs value is $>2.5$, it was decided that the number is a misconceived question.

\section{b. Conventional Biotechnology}

To find out students' understanding of conventional biotechnology sub-concepts, questions number $4,8,10$, and 13 were used. The highest percentage of students' misconceptions was obtained at number 10 , which was $14.28 \%$. In question number 10 students are asked to choose the characteristics of conventional biotechnology. This question is the number that is most misconceived by students, with a percentage of $14.28 \%$, this is also supported by the fraction of 0.78 or there are only 19 students who can answer the question 
correctly. In addition, when looking for the value of CRIs on this number, a value of 2.5 (> 2.5) is obtained, so it can be concluded that this number is a number that students misconceived.

Based on the results of student answers on the test questions, many students choose answers, namely the characteristics of conventional biotechnology consist of involving various disciplines, generally used for food needs, and techniques in the form of fermenting food ingredients by microorganisms, the direct use of microorganisms is generally used for food needs, and The technique is in the form of fermenting foodstuffs by microorganisms. Based on these answers, students only understand the concept partially, without going deep into it again, so that students are confused in choosing answers.

\section{c. Modern Biotechnology}

To find out students' understanding of conventional biotechnology sub-concepts, questions number 9, 12, 16, and 19 were used. The highest percentage of students' misconceptions was obtained at number 12 , which was $25 \%$. In question number 12 students were asked to determine the process of cloning sheep. This question is the number that is most misconceived by students, namely with a percentage of $25 \%$, this is also supported by the fraction which is 0.53 or there are only 17 students who can answer the question correctly. In addition, when looking for the value of CRIs on this number, the value is $2.76(>2.5)$ so it can be concluded that this number is a number that students misconceived.

Based on the results of student answers on the test questions, students chose many answers, namely the process of cloning sheep consisting of the ovum being destroyed by ultraviolet light - the nucleus of the donor somatic cell was taken - the nucleus of the donor somatic cell was taken the morula was implanted into the uterus of the ewe - the ovum divided several times form a morula - a baby lamb is ready to be born which is supposed to be from the ovum destroyed by ultraviolet light - the nucleus of the donor's somatic cell is extracted - the nucleus of the donor's somatic cell is extracted - the ovum divides several times to form a morula - the morula is implanted into the womb of the ewe - the baby lamb is ready born. Based on these answers, students only understand the concept partially, without going into it again, so that students are confused in choosing answers.

\section{d. Application of Biotechnology in Supporting Human Survival}

To find out students' understanding of conventional biotechnology sub-concepts, questions number $11,14,15,17,18$, and 20 were used. The highest percentage of students' misconceptions was obtained at number 14 , which was $32.14 \%$. In question number 14 students were asked to determine the negative impact of the application of biotechnology. This question is the number that students misconstrue the most, with a percentage of $32.14 \%$, this is also supported by the low fraction of 0.46 or there are only 17 students who can answer the question correctly. In addition, when looking for the value of CRIs on this number, a value of $2.66(>2.5)$ is obtained so it can be concluded that this number is a number that students misconceived.

Based on the results of student answers on the test questions, many students choose answers, namely the negative impact of the application of biotechnology, which can cause cancer which should cause allergic symptoms in the body. Based on these answers, students only understand the concept partially, without going into it again, so that students are confused in choosing answers.

Then continued with the interview, which selected only 5 students who had the highest misconceptions. Based on the results of interviews, it can be identified several possible causes of misconceptions in students, including:

\section{The student's own condition}

The occurrence of misconceptions in students is caused by incorrectly accepting the initial concept that is not right. Another reason is because of the students' thinking which has their own ideas that he creates. This means that students prioritize their feelings. Wrong reasoning is also one of the 
occurrences of misconceptions. Students misunderstood the concept material being taught.

\section{Resource materials}

The use of handbooks for students is very important, because books are the main source of learning, so that if students do not understand or forget the explanations given by the teacher, students can study them again in the book. In addition, by developing several combinations of online media in science learning, it can help teachers to provide meaningful learning (Hardinata $\mathrm{A}$, et al., 2020) so as to avoid misconceptions.

\section{Efforts that can be done in overcoming misconceptions}

There is some previous research literature on efforts to overcome misconceptions that have not gotten maximum results. Misconceptions that can be overcome sometimes reappear under certain conditions. When students face questions that are slightly distorted, sometimes misconceptions reappear and have the wrong influence. There are several elements that have been formulated by researchers on how to overcome misconceptions, including the following:

1) Identify students' preconceptions. What goes through students' minds before we start teaching? What preconceptions have been formed in students' minds about the experiences and events to be studied? What are the disadvantages of this preconception?

2) Preconceptions can be known from literature, from diagnostic tests, and from observations of student activities.

3) Designing a learning experience that starts from preconceptions by strengthening concepts that are correct and evaluating concepts that are still wrong. The main principle in evaluating misconceptions is that students carry out learning experiences that show conflicting concepts with natural events. Thus, it is hoped that there will be a conflict between the new experience and the old concept so that there will be a correction of the conception (cognitive dissonance theory, festinger). According to Piaget, the conflict between new experiences and wrong concepts will result in accommodation, namely the adjustment of cognitive structures that produce new concepts that are more appropriate.

4) Increase practice questions to practice new concepts and strengthen them. The questions that are worked on are actually chosen in such a way that the difference between the wrong and the correct concepts will appear clearly. What teachers can do to help students understand the correct concept is by discussing the problem by paying attention to and understanding the correct concept to students. Teachers don't just write lots of formulas on the blackboard or just do lectures without interacting with students.

In addition, learning planning is a teaching preparation that contains things that need or must be done by teachers and students in carrying out learning activities which include elements: selection of materials, methods, media, and evaluation tools (Simanjuntak MP, et al, 2020 ), taking into account this, is an attempt to avoid misconceptions.

\section{Conclusion}

Misconceptions in science learning often occur, especially in junior high school students. Provision of material preconceptions or differences in reasoning to students themselves can lead to misconceptions. Based on data analysis from the research of class IX students at MTsPN 4 Medan, the following conclusions can be drawn:

1. There was a misconception about science lessons, especially biotechnology material for class IX students at MTsPN 4 Medan in the 2021 academic year.

2. The level of misconception in the subconcepts of basic principles of biotechnology is $15.46 \%$, conventional biotechnology is $9.81 \%$, modern biotechnology is $17.85 \%$, and the application of biotechnology to support human survival is $18.44 \%$. 
3. The cause of student misconceptions can occur because of the individual himself, the briefing he received or the handbook.

4. The efforts that can be made to reduce the occurrence of misconceptions such as providing material according to the concept, detailed explanations, holding discussions and repeating learning by doing exercises or quizzes.

\section{Reference}

Astuti Fera, dkk. (2016). Identifikasi Miskonsepsi dan Penyebabnya pada Siswa Kelas XI MIA SMA Negeri 1 Sukoharjo Tahun Pelajaran 2015/2016 Pada Materi Pokok Stokiometri. Jurnal Pendidikan Kimia, 5, (2).

Darmojo, (1993). Science in History Jilid I. Jakarta.

Faizah, Kurniyatul. Miskonsepsi dalam Pembelajaran Ipa. Jurnal Darussalam: Jurnal Pendidikan, Komunikasi dan Pemikiran Hukum Islam, 8, (1), 115128.

Hardinata, A., Simatupang, H., Hanifa, F., Latip, A., Efwinda, S., \& Yogica, R. (2020). SURVEY ON THE EFFECTIVENESS OF ONLINE LECTURES DURING COVID-19 PANDEMIC: METHODS AND DIFFICULTIES. ISER (Indonesian science education research), 2(2).

Osborne, R., Freyberg, P.1987. Learning in Science: The Implications of Children's Science. Auckland: Heinemann

Simanjuntak, M. P., Sinaga, L., Hardinata, A., \& Simatupang, H. (2020). Pengembangan Program dalam Pembelajaran.

Syafril, Syafrimen. Identifikasi Miskonsepsi Dalam Pembelajaran Ipa Di Sekolah Menengah. Lampung. 